\title{
DISCHARGE OF PERSONAL LIABILITY ON MORTGAGE DEBTS IN NEW YORK:
}

\author{
BY MILTON R. FRIEDMAN†
}

Discharge of personal liability on mortgage debts in New York can be accomplished simply and effectively by satisfaction of the mortgage, delivery of a covenant not to sue, or any other adequate release. ${ }^{1}$ But mortgages are not paid and discharged with the same frequency with which titles change by conveyance or death. As a result, problems of discharge generally arise when the mortgagor is no longer owner of the mortgaged premises and when the mortgagor has had reason to belicve or expects that his mortgage obligations would be met by others.

This article will discuss discharge of mortgage liability by events suhsequent to conveyance by the mortgagor, rights of the mortgagor against subsequent owners of the land, and rights of the mortgagor against the holder of the mortgage. Inasmuch as the status of any obligor on the mortgage, with respect to subsequent owners, is similar to that of the mortgagor, ${ }^{2}$ it will be convenient to use the term "mortgagor" at times without reference to whether the liability in question was created at the inception of the mortgage or thereafter.

\section{Statute of Liamtations}

Payment of interest or part of the principal prevents the Statute of Limitations from running against a debt or revives a debt barred by the statute. Such payment is deemed to import an acknowledgment of the debt and a new promise to pay the residue dating from the time of payment. To be within the statute, however, case law requires that the payment be made by the party to be charged or somebody so authorized on his behalf.

Although there is some conflict, the New York rule is clear. One joint debtor cannot bind another by payment; a principal cannot bind a surety;

*This Article completes the subject discussed by the writer in Crcotion and Effect of Personal Liability on Mortgage Debts in New Yorle (1940) 50 YaLE L. J. 224 and The Enforcemeat of Personal Liability on Mortgage Debts in Neri Vork (1942) 51 YaL L. J. 382.

$\div$ Member of the New York and Connecticut Bars.

1. See Schenectady Savings Bank v. Ashton, 205 App. Div. 781, 782, 200 N. Y. Supp. 245, 247 (3d Dep't 1923).

2. There is no logical reason for distinguishing between a mortgagor and a person subsequently assuming. The two have been similarly treated, without question, in many of the cases cited in this article. Typical examples are: Kress v. Central Trust $C_{0}$., 246 App. Div. 76, 283 N. Y. Supp. 467 (4th Dep't 1935), aff'd, 272 N. Y. 629, 5 N. E. (2d) 365 (1936); Albany Exchange Savings Bank v. Winne, 168 Mise. 853,6 N. Y. S. (2d) 699 (Sup. Ct. 1938). 
a surety, a principal; an assignee of an insolvent debtor, his assignor; or an executor or administrator, the estate. ${ }^{3}$ And payments made on account of a mortgage debt by a grantee of mortgaged premises are deemed to be made by the grantee solely for his own protection and not as agent for or to bind the mortgagor-grantor. Consequently, when a mortgagor conveys the mortgaged premises, the Statute of Limitations begins running against his liability immediately upon the maturity of the debt, despite receipt from the owner by the mortgagee of all payments to which he is entitled. ${ }^{4}$

The relevant Statute of Limitations affecting mortgage liability has heretofore depended on the manner in which the liability was created, whether by the execution of a mortgage bond, the acceptance of a deed containing an assumption of the mortgage or by parol. ${ }^{5}$ But this problem is disappearing in New York by statutory changes reducing the Statute of Limitations on mortgage debts and other sealed instruments to six years, the same period as that applicable to simple contracts. ${ }^{6}$

3. See People's Trust Co. v. O'Neil, 273 N. Y. 312, 7 N. E. (2d) 244 (1937); Harper v. Fairley, 53 N. Y. 442 (1873); Granirer, The Sale of Pledged Collatcral, Part Payment and Other Transactions as Affecting the Statute of Limitations, N. Y. L. J., Aug. 25, 1938, p. 476, col. 1, Aug. 26, 1938, p. 486, col. 1; Payment On Account by Third Person as Affecting the Statute of Limitations, N. Y. L. J., Jan. 24, 1938, p. 372, col. 1.

4. See Brooklyn Savings Bank v. The Joseph Wechsler Estate, 259 N. Y. 9, 180 N. E. 752 (1932).

5. While negotiable instruments are commonly used in many jurisdictions to manifest a mortgagor's liability, the obligation is usually created in New York by a mortgage bond and repeated by a covenant in the mortgage. See Friedman, The Creation and Effect of Personal Liability on Mortgage Debts in New York (1940) 50 YALE L. J. 224, 225. In this event the Statute of Limitations affecting specialties is applicable. But this rule does not necessarily obtain with respect to mortgage liability assumed by a subsequent owner of the premises. Such liability may be created by acceptance of a deed including an assumption, though unsigned by the grantee, by agreement between the subsequent owner and the mortgagee or by parol. Id. at 226. But by statute, effective April 6, 1938, no assumption by deed is valid unless the assumption is executed and acknowledged by the grantee. See N. Y. Civ. PrAct. Act § 1083-c; Legislation (1938) 13 St. Jonn's L. REv. 215. The statute, however, refers only to a mortgage which "shall hereafter be executed" and apparently does not govern assumptions, made subsequent to its enactment, of mortgages theretofore executed. Insofar, therefore, as mortgage debts are validly assumed by parol, the Statute of Limitations affecting simple contracts is applicable. A more serious problem is presented when the assumption is based upon a deed unsigned by the grantee. The authorities, in general, are split as to whether such an obligation is a specialty or a simple contract, see Note (1927) 51 A. L. R. 981 ; cases cited in A. L. R. Blue Bk. of Supp. Dec. (1943) 446, but in New York a deed of this character is deemed to be the deed of both parties and the grantee's assumption a specialty. See Bowen v. Beck, 94 N. Y. 86 (1883) ; Futherer v. Agnew, 24 N. Y. S. (2d) 273 (Sup. Ct. 1941), aff'd, 261 App. Div. 876, 25 N. Y. S. (2d) 207 (4th Dep't 1941).

6. See N. Y. CIv. Prac. Act $\S \S 47,47 a$. 


\section{Modification of Mortgage by Agreenient Between Mortgagee and Subsenuent OWNer}

\section{Effect of Conveyance by Mortgagor}

To non-assuming grantee. As long as the mortgagor owns the premises, the relation between mortgagor and mortgagee is simple. The mortgagee is a secured creditor with remedies on the debt and on the collateral. But apart from this there is no occasion until a conveyance to draw a distinction between the mortgagor and the mortgaged premises. The conveyance is necessarily subject to the mortgage and passes only the "equity in the property," that is, an interest in the premises over and above the mortgage, whether the deed is silent on the mortgage or expressly subject to it, and whether or not the grantee assumes the mortgage. The mortgagee's remedy on the bond remains unaffected by the conveyance, ${ }^{7}$ and he may enforce payment of the debt against the mortgagor without foreclosure; in this respect the mortgagor remains a "primary" obligor. But since the grantee has bought only the equity and presumably paid only for the equity, he is not justified in holding the property free and clear of the mortgage. ${ }^{9}$ If, then, the mortgagor has paid the debt on maturity, he is entitled to the land for repayment. ${ }^{10}$ being in effect entitled to some of the rights usually vested in a surety. This is all that is meant by the oft-repeated statement that upon a conveyance the land becomes "primarily liable" for the debt." But if the

7. See Wagoner v. Brady, 221 App. Div. 405, 223 N. Y. Supp. 99 (3d Dep't 1927); Rochester Savings Bank v. Stoeltzen \& Tapper, 176 Misc. 140, 26 N. Y. S. (2d) 718 (Sup. Ct. 1941) ; Albany Exch. Bank v. Winne, 168 Mfisc. 853, 6 N. Y. S. (2d) 699 (Sup. Ct. 1938); Note (1926) 41 A. L. R. 317. For the mortgagee's choice of remedies and the qualifications of their use generally, see Friedman, The Enforcement of Personal Liability on Mortgage Debts in New York (1942) 51 Y YLE L. J. 382.

S. Where premises are convejed subject to a mortgage, there is a presumption that the amount of the mortgage has been deducted from the purchase price. Johnson v. Zinl:, 51 N. Y. 333, 337 (1873) ; 2 Jones, Mortgages (Sth ed. 1923) §911; 2 Posseror, Equit: JURISPRUDENCE (4th ed. 1918) $\$ 657 ; 3$ id. \$1205.

9. See Rochester Savings Bank v. Stoeltzen \& Tapper, 176 Mise 140, 143-44, $26 \mathrm{~N}$. Y. S. (2d) 718, 721 (Sup. Ct. 1941); Cherry v. Mfonro, 2 Barb. Ch. 618 (N. Y. 1848); 2 PodIERoY, op. cit. supra note $\$, \S 911 ; 3$ id. $\$ 1205$.

10. See Howard v. Robbins, 170 N. Y. 498, 63 N. E. 630 (1902); Schenectady Savings Bank v. Ashton, 205 App. Div. 781, 200 N. Y. Supp. 245 (3d Dep't 1923).

11. The statement that a conveyance of the mortgaged premises makes the land the primary fund for the debt appears in most of the relevant cases and literature. The rule is inapplicable where the circumstances are such as to impute an intention to the mortgagor to remain primarily liable, as where the purchase price approsimates the value of the fee unencumbered. And this despite the use of a quit-claim deed. See Wadsworth $v$. Lyon, 93 N. Y. 201 (1883). See also Wilbur v. Warren, 104 N. Y. 192, 196, 10 N. E 263, 264 (1887). On the other hand the rule does apply where both mortgager and grantee agree with the mortgagee to be liable. See Neukirch v. MIcHugh, $165 \mathrm{App}$. Div. $406,410,150$ N. Y. Supp. 1032, 1036 (1st Dep't 1914). It dues not give the grantee the 
mortgagee has foreclosed his mortgage and recovered a deficiency judgment against the mortgagor, the mortgagor has no right over against the land for reimbursement because foreclosure extinguishes all equity in the premises subordinate to the mortgage and with it the mortgagor's right over against the land. ${ }^{12}$

To assuming grantee. If the grantee assumes the mortgage, the grantec is, with respect to the mortgagor, primarily liable for the debt; and the mortgagor, only secondarily so. ${ }^{13}$ If, in this event, the mortgagor is compelled to pay the debt, he has two remedies to make himself whole, though but one satisfaction $:^{14}$ a judgment for reimbursement against the assuming grantee and his remedy against the land. If the mortgagee has foreclosed and recovered a deficiency judgment which the mortgagor is compelled to pay, the mortgagor may, though his right against the land is extinguished, recover over for the amount of the deficiency judgment. ${ }^{10}$ The relation between grantee and mortgagor in this situation is deemed to be that of principal and surety and is fully treated as such. Should the relationship be disregarded by the mortgagee, the mortgagor's liability may be discharged by application of the general rule that a creditor, knowing that his debtors are or have become principal and surety as to each other, whatever their original form of liability, cannot prejuclice the rights of the surety without releasing the surety in whole or in part. ${ }^{10}$

benefit of any collateral security for the mortgage debt in the hands of the mortgagee. Brewer v. Staples, 3 Sandf. Ch. 579 (N. Y. 1846); 2 JoNes, op. cit. supra note 8, $\$ 913$.

The rule of primary liability is said to have arisen where the grantee did not assume the mortgage, and in order to avoid unfairness to the mortgagor. See Rochester Savings Bank v. Stoeltzen \& Tapper, 176 Misc. 140, 143, 26 N. Y. S. (2d) 718, 721 (Sup. Ct. 1941). Yet another dictum indicates that even an unenforceable assumption will bring it into effect. Howard v. Robbins, 170 N. Y. 498, 503, 63 N. E. 530, 531 (1902). These dicta are misleading because the rule is applied regardless of personal assumption. Cf. Calvo v. Davies, 73 N. Y. 211 (1878); Murray v. Marshall, 94 N. Y. 611 (1884). The rule is said to govern the relationship between the mortgagor and grantec without effect on the mortgagee. This is but another way of saying that a conveyance does not bar a mortgagee from recovering against the mortgagor on the bond regardless of any assumption by the grantee. See Kmetz v. De Ronde, 231 N. Y. 641, 132 N. E. 921 (1921). Some cases state the land is "primarily liable" after a conveyance of the mortgaged premises to the mortgagee. This merely describes the limitations on the mortgagee's right to enforce payment of the debt after possessing himself of the mortgaged fec. Sec pp. 786, 787 infra.

12. See Comstock v. Drohan, 71 N. Y. 9, 13 (1877).

13. This applies to succeeding conveyances and if a succession of conveyances is accompanied by a chain of assumptions the liability for the mortgage debt is cast upon the grantees in the inverse order of assumption. See authorities cited in note 7 supra.

14. See McRae v. Pope, 311 Mass. 500, 42 N. E. (2d) 261 (1942); 4 Williston, Contracts (rev. ed. 1936) §1219.

15. See p. 790 et seq. infra.

16. 4 Williston, op. cit. sipra note $14, \S 1258$; Stenrns, Suretysuip (4th cd. 1934) $\S \S 23,90$. Familiar examples are a retiring partner, Colgrove v. Tallman, 67 N. Y. 


\section{Modification by Mortgagee and the Grantee Who Assumed}

\section{Mortgage by Agreenient with Mortg.agor}

The first reported case in New York to consider the effect on a murtgagor's liability of an extension agreement made between the mortgagee and a subsequent owner was Perkins $\%$. Squire, ${ }^{17}$ decided in 1873. The mortgagee brought an action at law in General Term on the bond against the mortgagor. The latter claimed that his conveyance to an assuming grantee made him a surety and that he was released by virtue of an extension agreement made without his consent. The court noted the defendant's failure to allege the duration of the extension and dismissed the defense as frivolous without fully appreciating its nature. ${ }^{18}$ Four years later when the same point was made in Moyer $\%$ Lathrop, ${ }^{10}$ the court reached the anamolous result ${ }^{20}$ that the mortgagor was a surety with respect to the assuming grantee but that this relationship was without effect on the mortgagee's rights. These cases were overruled by the Court of Appeals in Calvo $\approx$. Dazios ${ }^{21}$ where the suretyship relationship was held to affect the mortgagee; and the mortgagor, as surety, was held completely discharged by the extension made between the creditor and principal. The court assumed that if the mortgagor had paid the debt at its original maturity his right over against either the grantee or the land would be stayed during the extension and concluded that the mortgagor was affected by the modification made by the mortgagee and grantee varranting the release it decreed. The assumption that the mortgagor's rights

95 (1876), and a lessee who assigns his lease, Schieffelin v. Mocan Realty Corp., $233 \mathrm{~N}$. Y. 606,28 N. E. (2d) 24 (1940); Crowley v. Gormley, 59 App. Div. 256, 69 N. Y. Supp. 576 (2d Dep't 1901) ; Notes (1932) 41 YaLE L. J. 1239, (1935) 99 A. L. R. 1238.

17. 1 Thomp. \& C. 620 (N. Y. 1873).

18. The court seemed to assume that the extension agreement could be a defence only if it was unexpired at the inception of the action. It noted the defendant's failure to allege the duration of the agreement and therefore concluded there was no indicated prematurity.

19. 10 Hun 66 (2d Dep't N. Y. 1877), aff'd on other grounds, 73 N. Y. 315 (1873).

20. There was a conceptual difficulty in holding an assuming grantee a principal debtor of the mortgagee before the mortgagee was given a direct cause of action against the former. See Union Mlutual Ins. Co. v. Hanford, 143 U. S. 187, 190 (1892). Prior to Lawrence v. Fox, 20 N. Y. 268 (1859), a mortgagee could not recover on the mortgage bond against an assuming grantee but could recover a deficiency judgment on the theory of "equitable subrogation" to the rights of the mortgagor-grantor against the assuming grantee. For the distinction generally between the mortgagee's position under equitable subrogation and as a third-party contract beneficiary, see Friedman, sispra note 5, at 224, 230 et seq.

It should be noted that the surety relationship between mortgagor and grantee is predicated upon an agreement between the mortgagor and grantce (almost always affected through assumption by deed) and that an assumption of the mortgage by agreement between the grantee and the mortgagee leads to substantially different consequences. See pp. 779, 791 infra.

21. 73 N. Y. 211 (1878). 
are necessarily bound by the agreement between mortgagee and grantee is the logical basis of the decision. Although authority for this assumption, either pro or con, is scant, ${ }^{22}$ Calvo $v$. Davies represents the majority American view. ${ }^{23}$

Inasmuch as the creation of the suretyship relationship results from dealings between mortgagor and grantee, to which the mortgagee is generally not privy, it is clear that the mortgagee is not bound by the relationship under Calvo v. Davies unless he is cognizant of the grantee's assumption $^{24}$ at the time he makes a subsequent agreement with the grantee. ${ }^{25}$ The burden of proving this knowledge is on the mortgagor. ${ }^{20}$ Mere recordation of a deed to a grantee assuming the mortgage is not apt to come to the mortgagee's attention, and it has accordingly been held that recordation alone is not sufficient to charge a mortgagee with such knowledge. ${ }^{27}$

The suretyship relationship created by the mortgagor's conveyance to an assuming grantee continues after recovery of a money judgment against the mortgagor, and any such judgment may be released by an act which would have released the claim upon which it was founded. Thus, when a mortgagee recovered judgment against both mortgagor and assuming grantee, release of the judgment against the latter was held to release the former by operation of law. ${ }^{28}$

22. See p. 797 infra.

23. See Notes (1926) 41 A. L. R. 277, (1931) 72 A. L. R. 389, (1932) 81 A. L. R. 1016, (1938) 112 A. L. R. $1324 ; 41$ C. J. $719 ; 37$ AM. Jur. 357, $\$ 1056$ et scq.

24. See 4 Williston, op. cit. supra note $14, \S 1220$; cf. Dibble v. Richardson, 171 N. Y. 131, 63 N. E. 829 (1902); Grow v. Garlock, 97 N. Y. 81 (1884); Palmer v. Purdy, 83 N. Y. 144 (1880).

25. See Union Mutual Ins. Co. v. Hanford, 143 U. S. 187, 191 (1892); White v. Augello, 142 Misc. 233, 236-37, 254 N. Y. Supp. 228, 232 (Sup. Ct. 1931).

26. See White v. Augello, 142 Misc. 233, 254 N. Y. Supp. 228 (Sup. Ct. 1931); Star Fire Ins. Co. v. Waddington, 18 N. Y. W'kly Dig. 307 (Sup. Ct. 1883) ; Fidelity Union Trust Co. v. Prudent Investment Corp., 129 N. J. Eq. 255, 259, 19 A. (2d) 224, 227 (1941).

27. See White v. Augelio, 142 Misc. 233, 254 N. Y. Supp. 228 (Sup. Ct. 1931), and cases cited therein; Star Fire Ins. Co. v. Waddington, 18 N. Y. W'kly Dig. 307 (Sup. Ct. 1883) ; Stealens, op. cit. supra note $16, \$ 90$. Contra: Tousey v. Barber, 132 Misc. 861, 231 N. Y. Supp. 133 (Sup. Ct. 1928), (1929) 42 HARv. L. Rev. 583; Merrill v. Reiners, 14 Misc. 583, 36 N. Y. Supp. 634 (Sup. Ct. 1895). The only purpose of recordation is to notify subsequent purchasers and encumbrancers. Mead v. Bunn, 32 N. Y. 275, 278 (1865) ; 2 PoMeroy, op. cit. supra note $8, \S 657 ; 3$ id. $\S 1226$.

Where the mortgage is given by the mortgagor to secure another's debt the mortgagee is presumed to know of the principal-suretyship relation from the public records. See Bank of Albion v. Burns, 46 N. Y. 170 (1871).

28. See Wagoner v. Brady, 221 App. Div. 405, 223 N. Y. Supp. 99 (3d Dep't 1927); 4 Williston, op. cit. supra note $14, \S 1254$. See also In re Oster's Estate, 8 N. X. S. (2d) 249, 255 (Surr. Ct. 1938), aff'd, 258 App. Div. 930, 16 N. Y. S. (2d) 612 (4th Dep't 1939) ; Rosenfeld v. Levine, 249 App. Div. 142, 146, 291 N. Y. Supp. 474, 479 (1st 


\section{Modification between Mortgagee and Non-assuming Grantee}

When a mortgagor's conveyance runs to a non-assuming grantee, assimilation of the mortgagor and grantee to a surety-principal relationship runs into conceptual difficulties. In Penficld a'. Goodrich, an action for foreclosure and a deficiency judgment, the mortgagor's defense on the ground that he was released from persunal liability by virtue of an extension agreement made between the mortgagee and the grantec was unsuccessful. The court reasoned that the essence of suretyship is the existence of a principal and that the mortgagor could not be buth principal and surety. Thus there was no suretyship relationship, and its absence was not affected by the rule of "primary liability" of the land. Under this rule, according to the court, the mortgagor is subrogated on payment of the debt, not because he was a surety but because he has paid a delit charged upon the land of another and should, therefore, succeed to the creditor's rights.

Penfield a. Goodrich was overruled by the Court of Appeals in Murray v. Marshall, ${ }^{30}$ in which the mortgagor was released from the debt to the extent of the value of the property at the time of the extension agreement. The court stated that the grantee was not a debtor but that the land was primarily liable to the extent of its value in exoneration of the mortgagor. The mortgagor had a right, as against the grantee, that the land be first exhausted and this remedy could not be invaded with impunity. The extension agreement took this right away for the time being and placed a new, unagreed risk upon the mortgagor. In addition, the value of the premises and the mortgagor's right might have decreased and the debt increased. The mortgagee dealt with a grantee and, therefore, kntw of the conveyance. But the mortgagor was not wholly discharyed; he was a "quasi-surety" to the extent of the value of the land. The measure of his injury was his right of subrogation, value of the land, and the extension released him to this extent. From then on, the risk of future depreciation of the land was on the mortgagee. Thus the mortgagor was discharged only insofar as he was a "surety" and otherwise remained a principal debtor.

Under Mrurray 0 . Marshall the mortgagor is liable only for the amount by which the value of the premises falls short of equalling the debt. ${ }^{31}$

Dep't 1936) ; Bondy v. Aronson \& List Realties, 227 App. Div. 136, 140, 237 N. Y. Supp. 444, 48 (4th Dep't 1929). The rule was confused in Tousey v. Barber, 132 Mise. E51, 231 N. Y. Supp. 133 (Sup. Ct. 1928), criticised in (1929) 42 HAnv. L. REv. 583, where the mere recovery of a deficiency judgment against the murtgagor alone, in a fureelusure action in which the grantee was joined, was viewed as releasing the murtgagor per st.

29. 10 Hun 41 (2d Dep't 1877); aicord, Sheperd v. May. 115 U. S. 505 (1885).

30. 94 N. Y. 611 (1884).

31. See Union Bank v. Rubinstein, 78 Misc. 461, 138 N. Y. Supp. G4t (Sup. Ct. 1912), aff'd, 160 App. Div. 919, 145 N. Y. Supp. 1 (1st Dep't 1914), 216 N. Y. $7 u t, 111$ 
If, therefore, the mortgagee's action is for foreclosure the proceeds of the foreclosure sale are applied first to the debt on which the mortgagor is liable. ${ }^{32}$

Like Calvo v. Davies, Murray v. Marshall represents the majority American view. ${ }^{33}$ The two cases involve parallel rules but have at times been confused despite their difference in pleading, proof and the relief afforded ${ }^{34}$ Inasmuch as the defense under Murray $v$. Marshall is an affirmative defense, in the nature of confession and avoidance, the burden of proof thereunder is on the defendant and the value of the premises is to be pleaded and proved by the mortgagor. ${ }^{35}$

N. E. 1101 (1916). See also Matter of Piza, 5 App. Div. 181, 38 N. Y. Supp. 540 (1st Dep't 1896).

32. See Silverstein v. Brown, 153 App. Div. 677, 138 N. Y. Supp. 848 (1st Dep't 1912). See also Irving Trust Co. v. Hutchinson Holding Co., 241 App. Div. 107, 108, 270 N. Y. Supp. 684, 686 (1st Dep't 1934) ; Katz v. Mendelsohn, 260 N. Y. 434, 445, 184 N. E. 45, 98 (1933) (dissenting opinion). But cf. Meigs v. Cody, 139 Misc. 94, 247 N. Y. Supp. 467 (Sup. Ct. 1929), aff'd, 232 App. Div. 726, 247 N. Y. Supp. 893 (4th Dep't 1931) (grantee assuming specified items of mortgage debt liable for any deficiency up to limit of liability assumed).

33. See Commercial Casualty Ins. Co. v. Roman, 269 N. Y. 451, 199 N. E. 658 (1936) ; Metzger v. Nova Realty Co., 214 N. Y. 26, 107 N. E. 1027 (1915); cases collected in Stevens, Extension Agreements in the "Subject-To" Mortgage Siluation (1941) 15 U. of Cin. L. REv. 58, 58-60, and cases cited in note 23 supra.

Where negotiable mortgage notes are used in place of bonds, there is, however, some controversy. In this event the majority refuse to release a mortgagor where the mortgage is extended by agreement between mortgagee and a subsequent owner. The majority hold that NEGortable INSTRUMENTS LAw $\$ \$ 119,120,192$, providing for release of a secondary party, have no application to the maker, a primary party. The minority rely on Negotiable INSTRUMENTS LAw \$196, providing that the law merchant governs cases not otherwise covered by the Act. See the exhaustive discussion and collection of cases in Mortgage Guarantee Co. v. Chotiner, 8 Cal. (2d) 110, 64 P. (2d) 138 (1936), 108 A. L. R. 1080, 1088 (1937), (1937) 10 So. CaLtF. L. Rev. 511; Glenn, Purchasing Subject to Mortgage. Second Phase, Mortgagee's Rights Against Assuming Grantec (1942) 28 VA. L. REv. 445, 460-61; Suretyship Releases in the Law of Mortgages (1937) 4 U. or Chr. L. Rev. 469, 475. But see Keeler v. Templeton, 164 Misc. 113, 298 N. Y. Supp. 193 (Sup. Ct. 1937) (construing California law).

34. In Meldola v. Furlong, 142 Misc. 562, 255 N. Y. Supp. 48 (Sup. Ct. 1932), an action to foreclose and recover a deficiency judgment, the facts warranted a complete release of the mortgagor under Calvo v. Davies. The case was decided, however, under the rule of Murray v. Marshall and judgment given the mortgagee because of the mortgagor's failure to offer proof of the value of the property at the time of the extension.

35. See Feigenbaum v. Hiznay, 187 App. Div. 126, 175 N. Y. Supp. 223 (1st Dep't 1919); Wiener v. Boehm, 126 App. Div. 703, 111 N. Y. Supp. 126 (1st Dep't 1908). But see White v. Augello, 142 Misc. 233, 240, 254 N. Y. Supp. 228, 236 (Sup. Ct. 1931); Meuser v. Kirschbaum, 84 Misc. 259, 262, 145 N. Y. Supp. 677, 679 (Sup. Ct. 1914). 


\section{Modification by Mortgagee and Grantee Who Subseotently}

\section{AssuMred by AgreENTENT With Mortgagee}

A third situation arises often enough to merit more extended consideration than that found in the books. It involves a cunveyance by the mortgagor to a non-assuming grantee who subsequently assumes the mortgage by virtue of an extension or other agreement with the mortgaget. This is probably the most usual situation in the reported cases and seems to have been the one in Murray $v$. Marshall, though the opinion hardly noted it. When the point was expressly raised, the situation was held to be within the rule of Murray $r$. Mfarshall on the ground that an assumption of the mortgage, arising out of an agreement between grantee and mortgagee, creates no privity between grantee and mortgagor on which a suretyship relation may be predicated. ${ }^{30}$

\section{Contractual Prerequisites of Releasi}

General. The rules of Calio w. Dazies and Murray a. Marshall are, with a few exceptions already noted, similarly applied. The nature of the extension or modification agreement necessary to release the mortgagor, the necessity of consideration, establishment of a valid agreement and the like are the same whichever rule is applicable. Accordingly, the same authorities concerning the contractual prerequisites of release of the mortgagor are used herein whether the release in question is entire under Calc'o v. Dazies or pro tanto under Murray i'. Míarshall.

To release the mortgagor the agreement between the mortgagee and grantee must contain all the elements of a valid and en forceable contract. ${ }^{5 i}$ Since such an agreement constitutes an affirmative defense, the burden of establishing it is on the mortgagor. ${ }^{38}$ If the agreement purports to extend the mortgage, it must be of such a nature as to preclude the murtgagee from enforcing payment of the principal for the time being. ${ }^{39}$ An

36. See Feigenbaum v. Hiznay, 187 App. Div. 126, 175 N. Y. Supp. 223 (1st Dep't 1919); Matter of Piza, 5 App. Div. 181, 38 N. Y. Supp. 540 (1st Dep't 1896). Contra: Barden v. Sworts, 112 Misc. 384, 183 N. Y. Supp. 1S4 (Sup. Ct. 1920); Merrill v. Reiners, 14 Misc. 583, 36 N. Y. Supp. 634 (Sup. Ct. 1S95). See also Meuser v. Kirschbaum, S4 Misc. 259, 262, 145 N. Y. Supp. 677, 679 (Sup. Ct. 1914); Lillie v. MIeFarlin, 304 I1l. App. 27, 25 N. E. (2d) $S 96$ (1940). Compare text at pp. 775, 791.

37. See Eghert v. McGuire, 36 Misc. 245, 73 N. Y. Supp. 302 (Sup. Ct. 1901). See also Murray v. Marshall, 94 N. Y. 611, 616 (1884).

38. See Neukirch v. 1 IcHugh, 165 App. Div. 406, 150 N. Y. Supp. 1032 (1st Dep't 1914) ; Wiener v. Boehm, 126 App. Div. 703, 111 N. Y. Supp. 126 (1st Dep't 1908).

39. See Title Guarantee \& Trust Co. v. Weher, 30 Misc. 250, 63 N. Y. Supp. 224 (Sup. Ct. 1900) ; Jester v. Sterling, 25 Hun 344 (N. Y. 1881). See also Becker v. Faber, 280 N. Y. $146,150-51,19$ N. E. (2d) 997, 999-1000, 121 A. L. R. 1010, 1014 (1939) ; National Citizens' Bank v. Toplitz, 178 N. Y. 464, 466-67, 71 N. E. 1, 2 (1904); if. Moser v. Walker, 23 App. Div. 91, 48 N. Y. Supp. 341 (2d Dep't 1897). 
agreement that a mortgage would remain "open" if specified amortizations were made was held to be no extension on the ground that the mortgagee never relinquished his right to call the mortgage, ${ }^{40}$ but the same court subsequently held the contrary on facts difficult to distinguish. ${ }^{41} \mathrm{~A}$ mortgagor has been released by reason of an extension agreement made prior to the original maturity of the debt though a supervening foreclosurc prevented the inception of the extension. ${ }^{42}$ And the same result followed where the agreement was made after the debt had become due by its terms. ${ }^{43}$

Necessity of Consideration. The necessity of consideration in extension agreements has been a troublesome factor in New York, and statutory changes have recently sought to alleviate the difficulties. New York courts have firmly held that an agreement to extend the time of payment of a debt for a specified period upon the same terms as the initial obligation gives the creditor no more than that already owed him, is insufficient consideration and cannot prevent enforcement of the original claim. ${ }^{44}$

40. See Excelsior Savings Bank v. Cohen, 176 App. Div. 740, 163 N. Y. Supp. 1017, aff'd, 228 N. Y. 570,127 N. E. 912 (1920); cf. Merritt v. Youmans, 21 App. Div. 256, 47 N. Y. Supp. 664 (2d Dep't 1897).

41. See City Bank Farmers' Trust Co. v. Slowmach Realty Corp., 238 App. Div. 524, 264 N. Y. Supp. 786 (1st Dep't 1933), aff'd, 263 N. Y. 544, 189 N. E. 690 (1933).

42. See Barden v. Sworts, 112 Misc. 384, 183 N. Y. Supp. 184 (Sup. Ct. 1920); Merrill v. Reiners, 14 Misc. 583, 36 N. Y. Supp. 634 (Sup. Ct. 1895) ; SPEncer, SuretrSHIP (1913) §225.

43. See Syracuse Trust Co. v. First Trust \& Deposit Co., 141 Misc. 603, 252 N. Y. Supp. 850 (Sup. Ct. 1931).

44. See Olmstead v. Latimer, 158 N. Y. 313,53 N. E. 5 (1899); Title Guarantec \& Trust Co. v. Weiher, 30 Misc. 250, 63 N. Y. Supp. 224 (Sup. Ct. 1900); Metropolitan Life Ins. Co. v. Stimpson, 28 App. Div. 544, 51 N. Y. Supp. 226 (2d Dep't 1898); Moser v. Walker, 23 App. Div. 91, 48 N. Y. Supp. 341 (2d Dep't 1897).

The New York rule that extension agreements, without more, were unenforccable is fortunately followed by but a small majority of jurisdictions. See Note (1938) 48 YALE L. J. 149, 153, n. 21. An obligation for a fixed period is subject to neither call nor payment before maturity. 3 TiFFANy, REAL Property (2d ed. 1920) 2588, $\$ 640$. See Quackenbush v. Mapes, 123 App. Div. 242, 245-46, 107 N. Y. Supp. 1047, 1050 (1st Dep't 1908). The creditor receives an obvious advantage in the promise that his funds will produce income for the full period agreed on. The advantage is muttual in avoiding for both parties the dislocation, loss and expense attendant on compulsory refinancing and reinvestment at unexpected times. The debtor's relinquishment of his right to pay should be sufficient consideration. It was so held by the Appellate Division in the Olmustead case which was reversed on this point by the Court of Appeals. The value of a privilege to prepay is indicated by the frequency with which agreements giving this right to a debtor provide that its exercise shall be conditioned on payment of additional interest in compensation for the creditor's disadvantage thereby entailed. The Court of Appeals rejected this argument as "fanciful" in the leading case of Kellogg v. Olmstead, 25 N. Y. 189 (1862), where it held that an express covenant not to prepay was insufficient to validate an extension agreement. The court relied on cases involving extensions 
Thus, an agreement by an owner to assign rents to the mortgagee, when the mortgage itself provided for such an assignment, has been held insufficient consideration for the mortgagee's agreement to forbear. ${ }^{45} \mathrm{Ant}$ a grantee's assumption of the mortgage. included in an extension agreement, has been said to furnish no consideration if the grantee theretofore became liable by his deed or prior agreenent." Conversely, an agreement to pay by one under no antecedent obligation has been declared valid. ${ }^{47}$ Increasing the interest from a rate less than the legal one has been fuund insufficient in itself to constitute consideration since the creditor is entitled to the legal rate after maturity in any event. ${ }^{48}$ Similarly, a requirement by the mortgagee that interest be increased after maturity followed by payment thereof by a grantee not liable therefore has been held insufficient to render an extension enforceable. ${ }^{* 9}$ The same result has followed in cases in which a grantee, who had previously assumed the mortgage at; a lesser rate, affirmatively agreed to pay the increase.

by creditors in consideration of debtor's agreements to continue payment of interest and, in some cases, to pay part of the principal. These agreements had been held unenfurceable. The cases relied on seemed to have involved merely covenants of forbearance by creditors and permitting the debtors to pay at will. They were deemed relevant, however, in Kellogg $\approx$. Olunstead on the ground that a creditor's covenant to extend instics a debtor's covenant not to prepay. The court, therefore, imolied conditions retroactively in cases decided without reference thereto and thereon based a decision against logic, the overwhelming weight of authority and commercial desirability. The court ubserved in addition that inasmuch as the debtor was to pay only the legal rate of interest, the "value of the use of the money . . . fixed by law," there could be neither advantage nor disadvantage to debtor or creditor by the arrangement. By the same theory the damages given for breach of contract to make a loan are nominal, but even there consequential damages may be awarded. See Avalon Construction Corp. v. Kuirch Holding $\mathrm{C}_{0,}, 256$ N. Y. 137,175 N. E. 651 (1931). Had the parties agreed on interest other than the legal rate, the court's non sequitur would be more apparent. Furthermore, there is no necessary correlation between the market value of money and the legal rate of interest.

45. See Central Hanover Bank \& Trust Co. v. Romer Holding Co., 234 App. Div. 419, 255 N. Y. Supp. 254 (1st Dep't 1932).

46. See Neukirch v. MIcHugh, 165 App. Div. 406, 150 N. Y. Supp. 1032 (1st Dep't 1914).

47. See Jester v. Sterling, 25 Hun 344 (N. Y. 18S1) ; of. City Bank Farmers' Trust Co. v. Slowmach Realty Corp., 238 App. Div. 524, 264 N. Y. Supp. 786 (1st Dep't 1933), aff'd, 263 N. Y. 544, 189 N. E. 690 (1933). In Hunt v. Manville, 148 Mise. 5i, 264 N. Y. Supp. 153 (Sup. Ct. 1932), a grantee had assumed the mortgage in his deed from the mortgagor but his delivery of an interest-bearing note to the mortgagee for interest and part of the principal was held to validate an extension.

48. This would probably not hold true in the case of mortgages accasionally used which provide for a specified rate of interest until payment.

49. See N. Y. Life Ins. Co. v. Casey, 178 N. Y. 381,70 N. E. 916 (1904); Rafel v. Afaurer, 101 Mísc. 621, 167 N. Y. Supp. 941 (Sup. Ct. 1917).

50. See Neukirch v. McHugh, 165 App. Div. 406, 150 N. Y. Supp. 1032 (1st Dep't 1914). 
While the extension agreements discussed above contemplated postponements of the debt for specified periods, a different restilt might follow by estoppel if the duration of the extension were less specific. Thus, wherc the mortgagee agreed to "ride' along for a time," the mortgagor was held released on the ground that despite the absence of consideration the mortgagee was precluded from enforcing his claim until service of a notice to terminate and that until then a binding extension was created. ${ }^{b 1}$

The mischief of the New York rule invalidating many extension agreements was attacked in 1934 by a statute, ${ }^{52}$ providing in effect that an agreement to extend an obligation secured by real property should be valid without consideration if in writing and signed by the parties. This statute was promptly amended to authorize on the same terms a reduction in interest. ${ }^{53}$ The statute, however, applied only to agreements "between a creditor and obligee and a debtor, obligor, surety or guarantor," and would seem to have excluded from its benefits a grantee not assuming the mortgage debt. ${ }^{54}$ Subsequently the statute was broadened to provide that an agreement to change or modify or discharge in whole or in part any obligation "shall not be invalid because of the absence of consideration" if in writing and signed by the party to be charged.65 The languagc quoted has been criticised because of its negative phraseology and because it revives "the metaphysical concept of value" 56 and fails to provide, as its predecessors did, that the agreements are valid without consideration. The only reported decision concerning this statute assumed its adequacy. ${ }^{67}$ Its ultimate construction will probably validate all extension and modification agreements without consideration and thus carry out the obvious purpose it was intended to effect despite its dubious language. The entire question of consideration, however, must remain troublesome as long as pre-statutory situations are possible subjects of litigation and the statutes themselves require construction.

Reinstatement of mortgage as extension. Although New Yorkers have had difficulty in effecting extension agreements when, such has been their intention, it has been possible for them to stumble into a valid extension in-

51. See Syracuse Trust Co. v. First Trust \& Dep. Co., 141 Misc. 603, 252 N. Y. Supp. 850 (Sup. Ct. 1931). See also Veerhoff v. Miller, 30 App. Div. 355, 51 N. Y. Supp. 1048 (2d Dep't 1898).

52. N. Y. Laws 1934, c. 143 (effective April 5, 1934).

53. N. Y. Laws 1934, c. 898 (effective Aug. 24, 1934).

54. But $c f$. Matter of R. A. Securities Holdings, 46 F. Supp. 254 (E. D. N. Y. 1942), holding that mortgage participants may institute proceedings under Chapter $\mathrm{X}$ of the Bankruptcy Act as creditors of an owner not liable on a mortgage.

55. N. Y. Laws 1936, c. 281 (effective April 6, 1936). See (1937) 23 VA. L. Rev. 446; N. Y. LAW Revis. CoMrs. (1936) 81-374.

56. Note (1938) 48 YALE L. J. 149, 153, n. 21.

57. Greenwich Savings Bank v. Cabin Holding Co., 176 Misc. 89, 26 N. Y. S. (2d) 791 (Sup. Ct. 1941). No appeal was taken in this case. 
advertently. Ost a'. Mindlin, ${ }^{\text {ss }}$ involving an action on a mortgage hond against a guarantor, presents one such situation. In an earlier foreclosure suit, brought against both the owner and guarantor, plaintiff had declared the principal due pursuant to an acceleration clause in the mortgage. Thereafter the owner cured defaults on which the foreclosure was based and the mortgagee, owner and guarantor stipulated to discontinue the fureclosure. ${ }^{59}$ It was later held in the subsequent action that the discontinuance of the foreclosure, by annulling the acceleration and reinstating the mortgage, constituted an extension releasing the guarantor despite the guarantor's consent to the discontinuance. The court relied on Kilpatricls $\approx$. Germania Life Insurance Company in for the proposition that a mortgagee may not recall an acceleration without the mortgagor's consent. But the Kilpatrick case merely held that acceleration permits a mortgagor to pay the mortgage despite the mortgagee's effort to reinstate the mortgage for the purpose of imposing upon an earlier payment such a condition as a prepayment bonus. Inasmuch as the reinstatement in the $O$ st case restored the original maturity, the guarantor was subjected to neither increased risk nor a "new contract"-factors most often emphasized in the release of a surety. Furthermore, the reinstatement removed the guarantor's default as well as the owner's and reduced the guarantor's liability ly the payment accompanying the settlement. Nevertheless, there are at least some dicta which would seem to support the Ost case. ${ }^{\text {i1 }}$

58. 170 App. Div. 558, 156 N. Y. Supp. 695 (1st Dep't 1915), offd, 224 N. Y. 643, 121 N. E. 882 (1918).

59. The guarantor's participation in the stipulation of discontinuance was apparently on his understanding that arrangements were being made for payment of the mortgage without recourse to him. This only makes clearer the holding of the case that in the absence of affirmative consent reinstatement to original maturity, without more, is an "extension."

60. 183 N. Y. 163,75 N. E. 1124 (1905).

61. Walsh v. Henel, 226 App. Div. 198, 235 N. Y. Supp. 34 (4th Depit 1929) invulvcd facts similar to the Ost case except that the complaint in the prior foreclosure sought to foreclose for the full principal, prior to maturity, without expressly eleeting to acselerate. The majority of the court ruled there was no reinstatement or release because the mortgage had never become due. Apparently the mortgagee would have released his obligor if he had drawn his foreclosure complaint properly. In Adler v. Berkowitz, 229 App. Div. 245, 240 N. Y. Supp. 597 (2d Dep't 1930), rev'd, 254 N. Y. 433, 173 N. E. 574 (1930), the mortgage provided it would become due 20 days after an interest default though the bond provided for acceleration 30 days after default at the obligee's option. The Appellate Division held the mortgagee's acceptance of interest from the grantee 26 days late a reinstatement releasing the mortgagor. The reversal was based on the rule making a bond prevail over the mortgage in the event of repugnance between the two and a holding that the mortgage had never matured. Neither court mentioned the rule whereby an acceleration clause, being for the creditor's benefit, operates only at the creditor's election. See Born v. Schrenkeisen, 110 N. Y. 55, 17 N. E. 339 (1883); Matter of Steinway's Estate, 174 Misc. 55t, 21 N. Y. S. (2d) 31 (Surr. Ct. 1940). But ef. First National Bank v. Marcher, 179 Misc. 258, 38 N. Y. S. (2d) 774 (Sup. Ct. 1942). In 
Receipt of interest in advance as extension. A second method of inadvertent extension is possible when the mortgage is past dtte. Acceptance of an interest installment before it is due creates a presumption that the principal has been extended to the day when it will be fully earned. The court in Germania Life Insurance Company ${ }^{\prime}$. Casey ${ }^{62}$ indicated that this presumption does not arise if the mortgagee "expressly reserves the right at any time to return the surplus of interest or apply the same on the principal," but actually held that prepayment of interest by onc day releases the mortgagor when the mortgagee fails to rebut the presumption. Attorney Cardozo's successful advocacy in the Germania case did not restrain him from pungent criticism of its doctrine seventeen years later. ${ }^{03}$ Although it still represents the majority American view, ${ }^{84}$ there are indications that the Germania case is beginning to fare ill by the gentle alt of distinction. In New York Life Insurance Company v. Casey, ${ }^{05}$ payment of the January 1 interest installment on Friday, December 29, was held insufficient to presuppose an extension when New Year's clay fell on a Monday, preceded by a Sunday and a half holiday. In the recent casc of Kings County Trust Company 2 . Giozinco ${ }^{60}$ the Court of Appeals refused to apply the Germania doctrine where a bank received interest a few days in advance but proved at the trial that it concluded no extensions without prior submission to its president or vice-president and no such submission had been made. In view of the fact that these cases arise almost invariably from the almost mechanical practice in lending institutions of mailing interest reminders in advance, and an occasionial overprompt response, the Giovinco case removes much of the sting of the doctrine without, however, ending the wasteful litigation it makes possible.

\section{Types of agreements constituting release}

General. ${ }^{67}$ While extension agreements are the most frequent type of contracts releasing a mortgagor, any modification will effect this result.

Federal Land Bank v. Shoemaker, 147 Misc. 308, 263 N. Y. Supp. 653 (Coutty Ct. 1933), the reinstatement was held as not a release because the mortgagor had made the settlement payment.

62. 98 App. Div. 88, 90 N. Y. Supp. 418 (1st Dep't 1904), aff'd zeithout opinion, 184 N. Y. 554,76 N. E. 1095 (1906).

63. Cardozo, The Nature of the Judicial Process (1921) 152.

64. See Tuttle v. Metropolitan Savings Bank, N. Y. L. J., Nov. 6, 1941, p. 1398, col. 1 (Sup. Ct.) ; East Side Savings Bank v. Scanlon, 146 Misc. 695, 262 N. Y. Supp. 790 (Sup. Ct. 1933) ; Granirer, The Acceptance of Prepayment of Interest as Effecting Extension of Debt, N. Y. L. J., Dec. 5, 1939, p. 1962, col. 1, Dec. 6, 1939, p. 1984, col. 1; (1927) 40 Harv. L. Rev. 789; Note (1929) 59 A. L. R. 988.

65. $178 \mathrm{~N}$. Y. 381,70 N. E. $916(1904)$.

66.266 N. Y. 137,194 N. E. 60 (1934).

67. For effect on mortgagor's liability of acquisition of mortgage by subsclutent obligor or owner, see text infra at p. 794. 
Subordination of a mortgage to a new ${ }^{\text {ss }}$ or increased ${ }^{69}$ prior lien, increasing the amount of the mortgage itself. ${ }^{70}$ or consolidating the mortgage with an additional mortgage ${ }^{71}$-all of which are in substance the same-discharge the mortgagor. Other modifications with the same effect include: changing interest periods from semi-annual to quarter-annual $;^{i 2}$ abrogating a provision for the release of parcels from the mortgage on payment of scheduled prices $i^{73}$ and pernitting a sale of the premises in partition free and clear of the mortgage. ${ }^{7 t}$

The New York Court of Appeals has repeatedly said that if a murtgage is modified there will be no inquiry as to whether the mortgagor has been damaged and that the extent of the injury is immaterial. ${ }^{75}$ But the word "modification" has become a word of art. A release of part of the murtgagee's security releases the mortgagor only to the extent of the value of the released security. ${ }^{\text {TC }}$ And even a valid extension of time of payment of part of the principal constitutes a release only of the installment su, extended. ${ }^{\mathrm{T}}$ The mortgagor is not released by the mortyagee's receipt of

68. See Rosenfeld v. Levine, 249 App. Div. 142, 291 N. Y. Supp. 474 (1st Dep't 1936).

69. See Union Bank v. Rubinstein, 7S MFisc. 461, 138 N. Y. Supp. G4t (Sup. Ct. 1912), aff'd, 160 App. Div. 919, 145 N. Y. Supp. 1 (1st Dep't 1914), 216 N. Y. 766, 111 X. E. 1101 (1916) ; McDonough v. Mancuso, 234 App. Div. 161, 254 N. Y. Supp. 377 (3d Dep't 1931).

70. See Central Savings Bank v. Ritchey Realty Corp., 239 App. Div. 689, 268 X. Y. Supp. 700 (1st Dep't 1934).

71. See Toner v. Ehrgott, 226 App. Div. 244, 235 N. Y. Supp. 17 (1st Dep't 1929).

72. See Greenwich Savings Bank v. Cabin Holding Corp., 170 Mise. \$9, 26 X. Y. S. (2d) 791 (Sup. Ct. 1941). But see East N. Y. Savings Bank v. Morgenstern, N. Y. L. J., June 1, 1933, p. 3297, col. 5 (Sup. Ct.) (want of consideration).

73. See Paine v. Jones, 76 N. Y. 274 (1S79).

74. See Laird v. Wittkowski, 67 App. Div. 476, 73 N. Y. Supp. 1115 (1st Dep't 1902).

75. See Becker v. Faber, 280 N. Y. $146,149,19$ N. E. (2d) $997,999,121$ A. L. R. 1010, 1014 (1939) ; Murray v. Marshall, 94 N. Y. 611, 614 (18S4) ; Caliu v. Davies, 73 N. Y. $211,216(1878)$.

76. See Jackson v. Pescia, 124 N. Y. Supp. 735 (Sup. Ct. 1909), aff'd, 139 App. Div. 937, 124 N. Y. Supp. 1118 (2d Dep't 1910); MieRae v. Pupe, 311 Mass. 50u, 42 X. E.

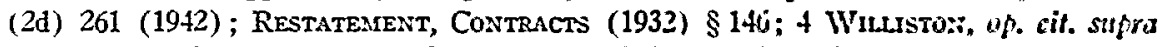
note $14, \$ \$ 1232,1234$; Spencer, SuretyshIP (1913) $\$ \$ 245-46$. Sce alsu Antisdel v. Wiiliamson, 165 N. Y. 372, 376, 59 N. E. 207, 208 (1901). But cf. Farmers' \& Merchants' State Bank v. Tasche, 53 S. D. 603, 222 N. W. 139 (1928), (1929) 42 H.Isv. L. REv. 712.

77. See Becker v. Faber, 280 N. Y. 146, 19 N. E. (2d) 997, 121 A. L. R. 1010, 1014 (1939) ; Cohn v. Spitzer, 145 App. Div. 104, 129 N. Y. Supp. 104 (4th Dep't 1911), aff'd on opinion below, 207 N. Y. 738, 101 N. E. 1098 (1913): Federal Land Bank v. Shoemalier, 147 MTisc. 308, 263 N. Y. Supp. 653 (Sup. Ct. 1933) ; + Wuruston, of. cit. sufra note 14 , $\$ 1222$. See also Katz v. Leblang, 243 App. Div. 421, 425-26, 277 N. Y. Supp. $\$ 50,855$ (1:t Dep't 1935), 35 Cor. L. Rev. 620. 
additional security without further stipulation on his part ${ }^{78}$ or by the compromise or reduction of past due interest. ${ }^{70}$ The Court of Appeals, while adhering to the traditional formula, recently held that an enforceable agreement for reduction of interest in futuro is not a "modification." 80 No passive act of a mortgagee will constitute a modification. ${ }^{\text {s1 }}$ The mortgagee is under no compulsion to enforce his rights with diligence, ${ }^{82}$ and an indulgence shown to a grantee or a delay to foreclose is no clefense to a mortgagor ${ }^{83}$ despite the accumulation of back interest and taxes thereby added to the latter's liability. ${ }^{84}$

Conveyance of Mortgaged Premises to Mortgagee. A conveyance to the mortgagee generally discharges the mortgage debt. ${ }^{85}$ But there is no unanimity even within New York to this effect. A conveyance with full warranties has been held a release, ${ }^{86}$ and a mere conveyance has been held to presume as much. ${ }^{87}$ A release in these circumstances includes the discharge of an additional mortgage held as collateral security ${ }^{88}$ even if the mortgagee intended to avoid merger of the principal mortgage. ${ }^{\text {st }}$

78. See Bangs v. Strong, 10 Paige 11, 16 (N. Y. Ch. 1842), aff'd, 7 Hill 250 (N. Y. Ct. Err. 1843) ; Union Trust Co. v. Toal, 28 N. Y. S. (2d) 956 (Stup. Ct. 1941) ; StEnkns, op. cit. supra note $16, \S 96$.

79. See Merritt v. Youmans, 21 App. Div. 256, 47 N. Y. Supp. 664 (2d Dep't 1897); Albany Exchange Savings Bank v. Winne, 168 Misc. 853, 6 N. Y. S. (2d) 699 (Sup). Ct. 1938).

80. See Becker v. Faber, 280 N. Y. 146, 19 N. E. (2d) 997, 121 A. L. R. 1010, 1014 (1939).

81. See Westchester Mortgage Co. v. McIntire, 174 App. Div. 525, 161 N. Y. Supp. 384 (2d Dep't 1916) ; Spencer, SuRETyship (1913) $\$ \$ 247-48$.

82. See Marshall v. Davies, 78 N. Y. 414, 421-22 (1879); Wiener v. Bochm, 126 App. Div. 703, 111 N. Y. Supp. 126 (1st Dep't 1908). See also text infra at p. 798.

83. See Olmstead v. Latimer, 9 App. Div. 163, 168, 41 N. Y. Supp. 44, 48 (2d Dep't 1896), modified on other grounds, 158 N. Y. 313, 53 N. E. 5, 43 L. R. A. 685 (1899); Mutual Life Ins. Co. v. Davies, 12 Jones \& S. 172, 188 (N. Y. Super. Ct. 1878) ; Hoftman v. Piccone, 137 Misc. 537, 538, 242 N. Y. Supp. 707, 709 (N. Y. City Cts. 1930).

84. See Union Bank v. Rubinstein, 78 Misc. 461, 138 N. Y. Supp. 644, aff'd, 160 App. Div. 919, 145 N. Y. Supp. 1 (1st Dep't 1914), 216 N. Y. 766, 111 N. E. 1101 (1916).

85. See 2 Jones, op. cit. supra note $8, \S \S 912,1213$; Note (1935) 95 A. L. R. 89 (1935). There is no merger, however, unless the same person is seized of the entiro property and the whole debt. No merger occurs, therefore, where a mortgagee acfuires an undivided part interest in the fee or a tenant in common acquires the mortgage. Clark v. Rowell, 163 Misc. 777, 298 N. Y. Supp. 232 (County Ct. 1937) ; Thonas, Montcacks (3d ed. 1914) \$391.

86. See Burnett v. Denniston, 5 Johns. Ch. 35 (N. Y. 1821).

87. See Hull v. Cronk, 55 App. Div. 83, 67 N. Y. Supp. 54 (2d Dep't 1900), dismisscd, 166 N. Y. 606,59 N. E. 1123 (1901).

88. See McGiven v. Wheelock, 7 Barb. Ch. 22 (N. Y. 1849) ; Wheelwright v. Loomer, 4 Edw. Ch. 232 (N. Y. 1843).

89. See Loomer v. Wheelwright, 3 Sandf. Ch. 135 (N. Y. 1845). 
On the other hand, there is authority making a conveyance to the mortgagee a release only to the extent of the value of the premiseswhich must be established by the mortgagor. 99 Two cases hold that a conveyance subject to the mortgage makes the land "primarily liable" and requires the mortgagee to forclose and credit the mortgagor with the valuce of the premises before maintaining an action for the debt. ${ }^{01}$ Preservation of the mortgage may be logically attributed to the mortgagee's desire to protect his title to the fee; hence, preservation of the mortgage alone ought not to imply reservation of rights on the bond, particularly where the conveyance is from a person who is liable for the mortgage debt and presumably expects to be released.

\section{Consent of MLrtgagor to Modification}

Stray dicta may indicate that a modification must be without the knuwledge or consent of the mortgagor in order to release his liability. ${ }^{02}$ But it is clear that neither knowledge nor failure to protest will preserve his obligation. $^{83}$ Nor is the mortgagor bound by the conduct of his atturney acting beyond the scope of his retainer. ${ }^{94}$ But actual participation by the mortgagor in procuring the modification is generally deemed a consent regardless of the particular capacity in which the mortgagor acts, ${ }^{85}$ unless

90. See Spencer v. Harford, 4 Wend. 381 (N. Y. 1830); if. Harrisen v. Hall, 239 N. Y. 51, 145 N. E. 737 (1924) (chattel mortgage). The Spencer case malses the conveyance the equivalent of a foreclosure and seems to be an application of the doubtiul ruling by Kent in Dunkley v. Van Buren, 3 Johns. Ch. 330 (N. Y. 181S), that foreclosure is an action solely in rem. See Friedman, The Enforcencut of Persunal Liability ans Mortgage Debts in Neri York (1942) 51 YaLE L. J. 382-83, 410.

91. See Eagan v. Engeman, 125 App. Div. 743, 110 N. Y. Supp. 3t5 (1st Dep't 1908) ; Central Hanover Bank \& Trust Co. v. Roslyn Estate, Inc., 266 App. Dir. 244, 42 N. Y. S. (2d) 130 (2d Dep't 1943). See also Vanderkemp v. Shelton, 11 Paige 23,34 (N. Y. Ch. 1844). But cf. Railroad Federal Savings \& Luan Ass'n v. United States, 135 F. (2d) 290 (C. C. A. 2d, 1943), which, in fixing the amuunt of deed stamps required, holds in effect that a conreyance to a mortgagee, expressly subject to the mortgage, cancels the debt.

92. See, e.g., N. Y. Life Ins. Co. v. Casey, 178 N. Y. 381, 387, 70 N. E. 916,917 (1904) ; Hyde v. Miller, 45 App. Div. 396, 400, 60 N. Y. Supp. 974, 977 (4th Dep't 1899), aff'd, 168 N. Y. 590,60 N. E. 1113 (1901).

93. See MrcDonough v. Mancuso, 234 App. Div. 161, 254 N. Y. Supp. 377 (3d Dep't 1931) ; Grace v. Wilson, 139 Misc. 757, 250 N. Y. Supp. 212 (Sup. Ct. 1931) ; Stransis, op. cit. supra note $16, \$ 94$.

94. See Rosenfeld v. Levine, 249 App. Div. 142, 291 N. Y. Supp. 474 (1st Dep't 1935); Magnus Beck Brewing Co. v. Setel, 130 Misc. 705, 225 N. Y. Supp. 41 (Sup. Ct. 1927).

95. That is, where he is personally liable as mortgagor and executes an agreement as officer of the corporate owner or consents to the agreement as holder of a sccond mortgage. See M. H. Metal Products Corp. v. April, 251 N. Y. 146, 167 N. E. 201 (1929); National Radiator Co. v. Hull, 79 App. Div. 109, 79 N. Y. Supp. 519 (2d Dep't 1903); Pinchot v. Roskam, 123 Misc. 253, 204 N. Y. Supp. 782 (Sup. Ct. 1924); East X. X, Savings Bank v. Morgenstern, N. Y. L. J., June 1, 1933, p. 3297, cul. 5 (Sup. Ct.). See 
he expressly disclaims a continuance of liability ${ }^{96}$ or the modification made exceeds the scope of the consent. ${ }^{97} \mathrm{~A}$ mortgagor may consent in advance to future modifications by inclusion of a survival clause in the mortgage or other instrument agreeing that his liability will not be discharged by subsequent agreements. ${ }^{98}$ But such clatses are construted strictly against the mortgagee ${ }^{09}$ and do not prevent a discharge of liability where the modification exceeds the scope of the consent. ${ }^{100}$ And they do not prevent the running of the Statute of Limitations in favor of the mortgagor. ${ }^{101}$ A mortgagor's consent to a modification may be by parol. ${ }^{102}$ He may ratify a modification, without new consideration and reinstate his liability, provided he knows the modification releases his original liability. ${ }^{103}$

also cases cited in Industrial Container Co. v. Slobodkin, N. Y. L. J., Nov. 15, 1940, p. 1571, col. 1 (N. Y. City Cts.).

96. See Irving Trust Co. v. Hutchinson Holding Corp., 241 App. Div. 107, 270 N. Y. Supp. 684 (1st Dep't 1934).

97. See Schuck v. Kings Realty Co., 260 App. Div. 1021, 23 N. Y. S. (2d) 764 , aff'd, 285 N. Y. 750,34 N. E. (2d) 907 (1941).

98. See Metropolitan Life Ins. Co. v. Stimpson, 28 App. Div. 544, 51 N. Y. Supp. 226 (2d Dep't 1898) ; Kohn v. Beggi, 147 Misc. 701, 264 N. Y. Supp. 274 (Sup. Ct. 1933) ; Notes (1935) 94 A. L. R. 1447, (1938) 117 A. L. R. 964 . There may be a tax disadvantage in survival clauses in that they make an extension with an individual owner of a mortgage made by a corporation, a renewal of a corporate obligation and thus stibject to federal stamp tax.

99. See Mutual Life Ins. Co. v. Rothschild, 160 N. Y. Supp. 164 (Sup. Ct. 1916), modified on other grounds, 177 App. Div. 883, 163 N. Y. Supp. 1124 (1st Dep't 1916), 226 N. Y. 599, 123 N. E. 880 (1919) (grantee's agreement to "comply" with the terms of the mortgage did not subject him to a survival clause included in the original mortgage); Irving Trust Co. v. Hutchinson Holding Co., 241 App. Div. 107, 270 N. Y. Supp. 684 (1st Dep't 1934) (survival clause in collateral bond respecting further agreements between mortgagee and subsequent owners held inapplicable to agreement with the original owner) ; Excelsior Savings Bank v. Cohen, 176 App. Div. 740, 163 N. Y. Supp. 1017 (1st Dep't 1917), aff'd, 228 N. Y. 570, 127 N. E. 912 (1920) (mortgagor's liability limited to original interest though rate increased by subsequent agreement).

100. Survival clauses authorizing extension agreements have been insufficient to prevent discharge of liability when the extension agreements included additional clauses generally common to extension agreements. Schuck v. Kings Realty Co., 260 App. Div. 1021, 23 N. Y. S. (2d) 764 (2d Dep't 1940), aff'd, 285 N. Y. 750, 34 N. E. (2d) 907 (1941) ; Matter of Raisler, N. Y. L. J., June 6, 1939, p. 2606, col. 7 (Surr. Ct.) ; and cf. Metropolitan Life Ins. Co. v. Aeon Realty Co., N. Y. L. J., Jan. 17, 1933, p. 323, col. 4 (Sup. Ct.) (mortgagor released where principal of mortgage increased after reduction).

101. See Smith v. Wagner, 106 Misc. 170, 174 N. Y. Supp. 205 (Sup. Ct. 1919).

102. 4 Williston, op. cit. supra note $14, \S 1223$.

103. See Carpenter v. Hogan, N. Y. L. J., July 31, 1943, p. 221, col. 1. (Sup. Ct.), which collects the authorities; 4 WILlISTON, op. cit. supra note $14, \S 1223 ; 1$ BRANDT, Suretyship and Guaranty (3d ed. 1905) §381; Pingrey, Suretysmip and Guaranty (2d ed. 1913) $\$ 101 ; 50$ C. J. 193, 194, 254; cf. Schwartz v. American Surety Co., 231 Mass. 490,121 N. E. 424 (1919). 


\section{Reserzation of Rights against Mortgagor and Extcusion on Condition}

A mortgagee may probably dispense with his mortgagor's consent to an extension agreement without loss of the latter's liability by reservation of his rights against the mortgagor in accordance with the general rule that a creditor may deal with the principal and reserve his rights against the surety. ${ }^{104}$ Reservation of creditor's rights as applied to mortgage extensions leaves the mortgagor an unconditional right to pay the mortgage after the original maturity and enforce any right of subrogation or reimbursement in disregard of the extension created between the mortgagee and grantee. The extension is, therefore, without effect un either the mortgagor's rights or liability.

In order to thus maintain the status quo the reservation must be unambiguous. ${ }^{105}$ The agreement in Cali'o ${ }^{\prime}$. Dazics ${ }^{100}$ provided that the bond and mortgage "should remain in every other respect unaffected by said agreement." In Metzger $\approx$. Noc'a Realty Company, ${ }^{107}$ the agreement stated, "Nothing herein contained shall impair the security now held for the debt or any condition . . . in said bond and mortgage. . .." In both cases the Court of Appeals held the language quoted insufficient to effect a reservation, but did not foreclose the possibility that the rule applies in mortgage situations. ${ }^{108}$

Apart from the difficulties of strict construction the practical objection to reservation, and undoubtedly the reason for its rarity in mortgage extensions, is that it does not give the grantee an unconditional extension but possibly a mere substitution of creditors. ${ }^{100}$ Despite the abstract logic of the doctrine of reservation of rights against the mortgagor, it tends to remove, at least for the duration of the extension, an induce-

104. See Palmer v. Purdy, 83 N. Y. 144 (1880) ; Note (1941) 50 YALE L. J. 1485; Restatearent, Security (1941) \$122. See also Report of N. Y. Law Revis. Coms. (1937) 907-10; STEARNS, op. cit. supra note 16, 92.

105. See Mrorgan v. Smith, 70 N. Y. 537, 546 (1877).

106. 73 N. Y. 211, 217 (1878).

107. 214 N. Y. $26,29-30,107$ N. E. 1027,1028 (1915) ; cf. Laird v. Wittlowski, 67 App. Div. 476, 73 N. Y. Supp. 1115 (1st Dep't 1902).

108. Gordon v. Maurno Realty Co., N. Y. L. J., Jan. 31, 1940, p. 493, col. 4 (Sup. Ct.), is apparently the only mortgage case directly in point in New York. There, an extension agreement was made expressly subject and subordinate to, and with reservation of, all rights of the mortgagor. The reservation was upheld and summary judgment given the mortgagee against the mortgagor. See Mfutual Life Ins. Co. v. Bainbridge Building Co., N. Y. L. J., July 10, 1943, p. 73, col. 5 (Sup. Ct.) ; cf. Union Trust Co. v. Tosl, 28 N. Y. S. (2d) 956 (Sup. Ct. 1941); and the concurring opinion in Lobee v. Williams, 226 App. Div. 211, 216, 234 N. Y. Supp. 649, 654 (4th Dep't 1929).

109. Professor Glenn argues that reservation is more likely to increase a surety's risl: in mortgage extensions than in commercial suretyship with short maturities. See Glenn, Purchasing Subject to Mortgage. Second Phase, Mortgagec's Rights Against Asstming Grantee (1942) 28 VA. L. Rev. 445, 461-62. 
ment to pay by the person enjoying the beneficial interest in the premises and having an affirmative interest in liquidating the mortgage lien.

An extension with reservation of rights against the surety has at times been regarded as an extension subject to the consent of the surety ${ }^{110}$ in which event the extension is nullified if the surety refuses. ${ }^{111}$ But this is not an extension with a reservation - in fact, the two are conceptually repugnant. An extension conditioned on consent is a nullity without consent, while an extension with a reservation can be affected without the surety's knowledge or consent. ${ }^{112}$ Any owner has sufficient interest to join with the mortgagee in an effective extension agreement ${ }^{113}$ and thereby fund the mortgage debt. If the owner and mortgagee are agreeable to an extension with reservation of the surety's rights, with its possible consequences, there is no reason why such an agreement should be subject to subsequent disruption by either on the fictitious assumption that the parties intended an extension on condition. This result may be drastic; a mortgagee may thereby be compelled, after a change of position, to refund a substantial amortization paid and accepted in good faith in connection with the abortive extension. ${ }^{114}$

\section{Mortgagor's Right of Reimbursement}

A mortgagor who has conveyed to an assuming grantee cannot recover judgment for the mortgage debt against his grantee merely becatse of maturity of the mortgage. 115 If the mortgagor were to receive such pay-

110. See Calvo v. Davies, 73 N. Y. 211, 217 (1878). See also 4 Wirurston, op. cit. supra note $14, \S 1230$, criticising the comparison as artificial.

111. See Bangs \& Alcott v. Strong, 10 Paige 11, 18 (N. Y. Ch. 1842), aff'd, 7 Hill 250 (N. Y. Ct. Errors 1843) ; Note L. R. A. 1915C 831.

112. See Report of N. Y. Law Revis. Comm. (1937) 908.

113. See Veerhoff v. Miller, 30 App. Div. 355, 358, 51 N. Y. Supp. 1048, 1050 (2d Dep't 1898). See also Schwartz v. Smith, 143 App. Div. 297, 300, 128 N. Y. Supp. 1, 3 (1st Dep't 1911), aff'd, 207 N. Y. 714, 101 N. E. 1121 (1913).

114. Compare Mehlhop v. Central Union Trust Co., 235 N. Y. 102,138 N. E. 751 (1923), where an owner, not liable on a mortgage, had paid the mortgagee $\$ 3,000$ in reduction of the mortgage in connection with a proposed extension which, because of a dispute, was never consummated. Subsequently, the mortgagee foreclosed and allowed credit on the mortgage debt for this payment. Thereafter, the owner recovered judgment for the $\$ 3,000$ on ground of failure of consideration.

115. See Ayers v. Dixon, 78 N. Y. 318 (1879). There is conflict among the states, which may not have been ultimately resolved in New York, respecting the mortgagor's right, before paying the mortgagee, to recover the amount of the mortgage debt from an assuming grantee. See Rawson's Adm'x v. Copland, 2 Sandf. Ch. 251 (N. Y. 1844), aff'd, 3 Barb. Ch. 166 (N. Y. 1848); Adams v. Symon, 22 Abb. N. C. 469,6 N. Y. Supp. 652 (Sup. Ct. 1889); McRae v. Pope, 311 Mass. 500, 42 N. E. (2d) 261 (1942); Notes (1922) 21 A. L. R. 504, 507 et seq., (1932) 76 A. L. R. 1191, 1194 el seq., (1935) 97 A. L. R. 1076, 1077. Besides the reason mentioned in the text, the mortgngor ought not be permitted to disrupt an understanding between mortgagee and grantee that the 
ment, the grantee's land would still be encumbered by the mortgage and yet he would have no assurance that the mortgagee's claim would be liquidated. If the mortgagor pays, he may recover over against his assuming grantee or any other owner in a chain of assumptions. ${ }^{110}$ But this is about all that is settled on the subject.

In three cases the mortgagor paid the mortgagee, sued the grantee for reimbursement, and then discorered that the mortgagee had released the grantee before the mortgagor paid the mortgage. While all three cases agree that the stipulations between mortgagee and grantee would have released the mortgagor had the point been timely raised, they disagree with respect to the mortgagor's right over after paying the murtgagee under these circumstances. In Hyde ${ }^{\prime}$. Miller ${ }^{112}$ the court held that the agreement between mortgagee and grantee could not affect the mortgagur if unknown to him. But in Knoblock i'. Zschicietske ${ }^{118}$ the court ruled that when the mortgagor failed to see the stipulation of release in the foreclosure record, he paid the mortgagee at his peril. In Lober i'. I' illiams ${ }^{119}$ it was indicated that the mortgagor would recover if, but only if, his payment to the mortgagee were made in ignorance of the grantee's release.

The right of reimbursement has also arisen between a mortgagee and a grantee who took the property subject to the mortgage but subsequently assumed by agreement between grantee and mortgagee. When mortgagors have claimed such agreements released them completely under Coli' 0 '. Davies, it has been held that they were not "sureties," but Murruy $z$ '. Marshall has been applied to release the mortgagors to the extent of the value of the property. ${ }^{120}$ The theory of the cases is that no privity exists between mortgagor and grantee by reason of an agreement between grantee

mortgage remain open, unless he brings a bill for exoneration or pruceds under Pain v. Packard, 13 Johns. 174 (N. Y. Sup. Ct. 1816). See text at p. 795 infro.

116. Comstock v. Drohan, 71 N. Y. 9 (1877); Taintor v. Hemmingway, 18 Hun 458 (3d Dep't N. Y. 1879), affd, 83 N. Y. 610 (1880) ; Notes (1922) 21 A. L. R. 507, 520, (1932) 76 A. I. R. 1191, 1196; see note 13 stpra. But see Keller v. Lee, 66 App. Div. 184, 72 N. Y. Supp. 948 (4th Dep't 1901).

The foreclosure of a blanket mortgage entitles any owner of part of the tract to recovery for the value of his parcel'against a purchaser of another part who assumsd the entire mortgage. Russell v. Pistor, 7 N. Y. 171 (1852). See Friedman, sisfra note 5 , at $248,249$.

117. 45 App. Div. 396, 60 N. Y. Supp. 974 (4th Dep't 1899), aff'd arithoust opinion, 168 N. Y. 590, 60 N. E. 1113 (1901).

118. 21 Jones \& Sp. 391 (N. Y. 1SS6). In both the Hyde and Firollocl: eases the grantees' release was by stipulation filed in the foreclosure action.

119. 226 App. Div. 211, 234 N. Y. Supp. 649 (4th Dep't 1929). The trial court was held in error in holding that the grantee's liability over to the mortgagor was res adjudicata by reason of the earlier foreclosure. It accordingly reversed a judgment for the plaintiff and granted a new trial.

120. See text at pp. 775,779 supra. 
and mortgagee. The same rationale is applied to reimbursement cases based on the same situation. Accordingly, a grantee who assumed the mortgage by agreement with the mortgagee, and paid a deficiency judgment, cannot recover over against the mortgagor..$^{121}$ And, conversely, it seems that a mortgagor who has paid a deficiency judgment cannot recover over against such a grantee. ${ }^{122}$ The result leaves the ultimate liability for the mortgage debt entirely to the mortgagee's caprice. Query, as to the incidence of liability between mortgagor and grantee in this situation if the mortgagee should recover judgment against both in the same action.

Although the Court of Appeals has never been faced with this situation, two cases are fairly comparable. In Commercial Casualty Insurance Company $v$. Roman ${ }^{123}$ the mortgagor had conveyed the premises stibject to the mortgage. The mortgagee gave an extension to a subsequent owner in consideration of a collateral bond, of the owner and a surety company,

121. See Winslow v. Stoothoff, 104 App. Div. 28, 93 N. Y. Supp. 335 (2d Dep't 1905 ) ; cf. Mutual Life Ins. Co. v. Hall, 31 App. Div. 574, 52 N. Y. Supp. 404 (2d Dep't 1898 ), aff'd, 166 N. Y. 595, 59 N. E. 1127 (1901).

122. In Mutual Life Ins. Co. v. Bainbridge Building Co., N. Y. L. J., July 31, 1942, p. 243, col. 6 (Sup. Ct.), a mortgagor, who had agreed to remain liable despite mortgage modifications between the mortgagee and subsequent owners, conveyed the property stibject to the mortgage. Thereafter, the grantee, in an agreement with the mortgagec, assumed the mortgage and, simultaneously, gave the mortgagee a collateral bond of $H$. After default the mortgagee agreed, in consideration of a $\$ 12,000$ payment, not to scek a deficiency judgment against either the grantee or $H$. Thereafter the mortgagec foreclosed and sought a deficiency judgment against the mortgagor alone. The mortgagor" moved to interplead $H$ as a party defendant liable over to the mortgagor. This motion was denied with the following opinion:

"At the time the moving defendant sold the mortgaged property to the defendant Bainbridge Building Corporation the latter did not assume the mortgages. The execttion by Bainbridge Building Corporation some time thereafter of an extension agrecment with the plaintiff, to which the moving defendant was not a party, did not have the effect, as between the defendant and Bainbridge Building Corporation, of making the former a mere surety to the mortgagee. . . . It follows that the moving defendant has failed to show that the defendant whom it proposes to bring into the action will be liable over it in the event of a recovery by the plaintiff. The motion to bring in an additional defendant is accordingly denied." Ibid.

On motion for reargument the court adhered to its original determination and wrote a similar opinion. See N. Y. L. J., Oct. 23, 1942, p. 1155, col. 4, aff'd vithout opinion, 265 App. Div. 996, 39 N. Y. S. (2d) 996 (1st Dep't 1943). Leave to appeal was denicd in 265 App. Div. 1052, 41 N. Y. S. (2d) 192 (1st Dep't 1943). On the subsequent trial the mortgagor was held liable for any deficiency judgment despite its claim of release by reason of the mortgagee's covenant to seek no deficiency judgment against either the grantee or $H$. See N. Y. L. J., July 10, 1943, p. 73, col. 5 (Sup. Ct.). In a companion action brought by the mortgagor against $H$, the mortgagor sought a determination that $H$ would be liable to the mortgagor for any sum payable by the latter to the mortgagee. The mortgagor's complaint was dismissed. See 37 West 57 th Street Co. v. Hearst, N. Y. L. J., July 10, 1943, p. 73, col. 7 (Sup. Ct.).

123. 269 N. Y. 451,199 N. E. 658 (1936). 
conditioned on payment of the mortgage. When the premises were sold under a prior lien, the surety company paid the mortgage and sued the mortgagor. The mortgagor claimed a release by reason of the extensi in agreement. The case was argued and decided on the theory that Murray a. Marshall governed and that, therefore, the mortgagor was liable fur the mortgage debt less the value of the property at the time of the $\mathrm{cx}$ tension. On this basis the surety company recovered judsment against the mortgagor. If the position of the surety company, which was derived from the grantee, is the same as that of the grantee, the result malies the mortgagor's liability primary as against the grantee and. in effect. sives the grantee a cause of action against the mortgagor.

In Katz $v$. Mendelsoln, ${ }^{124}$ decided three years before the Roman case. an owner sold his property and received a purchase muney murtgage in part payment. He assigned the mortgage and guaranteed its payment. The grantee resold the premises subject to the mortgage which the second grantee did not assume. The assignee of the mortgage instituted fureclosure and procured a receiver of the rents. The then owner had the receiver discharged by filing a bond. of herself and a surety comprany. conditioned upon payment of any judgment recovered in the fureclosure. A deficiency judgment was recorered against the mortgagee-guarantur, which was paid by the surety company taking an assignment to enforce the judgment against the mortgagee. The Court of Appeals canceled the judgment against the mortgagee, noting that the surety complany hal guaranteed payment of a deficiency judgment at the behest of a subsequent owner who thereby became revested with rents which would utherwise have been credited against the mortgagee-guarantor's liability. ${ }^{125}$ But "the principle of law governing the determination of this case," wrote the court, is that one becoming a surety for a debt during an action against the principal is not a co-surety and not entitled to contribution.

If the position of the mortgagee-guarantor in the Katz case be viewed as that of a mortgagor, which in effect he was, the Court of Apyeals may be deemed to have held that an assuming grantee may not, after payment. recover over against the mortgagor. The theory upon which the decision was predicated, however, was a narrow point of suretyship law unconnected with mortgages.

The general approach in all these cases seems highly questionable. The majority opinion in the Katz case states, in passing, that an extensiun of the right of subrogation against the mortgagee-guarantor wuuld give

124. 260 N. Y. 434,184 N. E. 45 (1933), 46 HARI. L. REv. 1344 ; (1933) 10 N. Y. U. L. Q. REv. 546.

125. The court also noted the absence of evidence of the amuunt uf such rents.

126. The dissenting judge argued that the mortgagee-guarantor should be held liable but with a credit for the rents freed by the surety company bond. $260 \mathrm{~N}$. Y. 43\%, 441, 184 N. E. 45,47 (1933). 
the later owner a right she would not have if she had paid the mortgage before the foreclosure and would charge the mortgagee with an obligation she had assumed. ${ }^{127}$ But this approach was not developed in the opinion and did not govern the determination of either this or the later Roman case. It is submitted, however, that this is the proper approach to the question. When a purchaser of mortgaged property takes the premises subject to a mortgage, his purchase price is thereby reduced. ${ }^{128}$ If he pays the mortgage debt during his ownership, the liability of the mortgagor is thereby discharged whether the grantee assumed ${ }^{120}$ the mortgage by deed or took subject thereto. ${ }^{130}$ The grantee cannot avoid this by taking an assignment in the name of a nominee. ${ }^{131}$ In view of the fact that the grantee enjoys the beneficial interest in the property and its rents and profits, this result is eminently fair. On this basis it would seem that payment of the debt in the Katz and Roman cases by either the subsequent owners, their sureties, or anybody claiming through the owners should have discharged the mortgagor or original guarantor without more. And a grantee who assumes the debt by subsequent agreement with the mortgagee, and thereafter pays a deficiency judgment, should never be entitled to full reimbursement against a mortgagor despite lack of privity between grantee and mortgagor. At most there should be contribution between the two, for any co-debtor ${ }^{132}$ or co-strety ${ }^{133}$ is en-

127. 260 N. Y. $434,438,184$ N. E. 45,46 (1933).

128. See text at p. 773 supra.

129. See Matter of Browne, 35 Misc. 362, 71 N. Y. Supp. 1034 (Surr. Ct. 1901); 2 PoMeroy, op. cit. supra note $8, \S 797 ; 2$ TifFanY, op. cit. supra note 44 , at $2612, \S 640$. See also Ayers v. Dixon, 78 N. Y. 318, 323 (1879); cf. text at p. 791 supra.

If a purchaser of part of a mortgaged tract assumes the entire debt and then acquires the mortgage, the remaining premises are thereby freed of the mortgage lien. Wilcos v. Campbell, 35 Hun 254 (5th Dep't N. Y. 1885), aff'd, 106 N. Y. 325, 12 N. E. 823 (1887). See Friedman, stipra note 5, at 248-49.

130. See Lagrave v. Hellinger, 144 App. Div. 397, 129 N. Y. Supp. 291 (1st Dep't 1911), aff'd, 205 N. Y. 577,98 N. E. 1106 (1912); Mathews v. Aikin, 1 N. Y. 595 (1848); Armstrong v. Purcell, 74 App. Div. 623, 78 N. Y. Supp. 36 (2d Dep't 1902); 2 JoNeS, op. cit. supra note 8; 2 TIFFANY, op. cit. supra note 44 at 2666, $\$ 646$. But cf. Southworth v. Scofield, 51 N. Y. 513 (1873); Bock v. Gallagher, 114 Mass. 28 (1873).

131. See Lagrave v. Hellinger, 144 App. Div. 397, 129 N. Y. Supp. 291 (1st Dep't 1911), aff'd, 205 N. Y. 577, 98 N. E. 1106 (1912); Mathews v. Aikin, 1 N. Y. 595 (1848). Reassignment of a bond and mortgage, acquired by an assuming grantee, vests the assignee with no right to enforce the bond. Kellogg v. Ames, 41 N. Y. 259 (1869); Ely v. McNight, 30 How. Pr. 97 (N. Y. Sup. Ct. 1864).

132. See Weed v. Calkins, 24 Hun 582 (3d Dep't N. Y. 1881); 3 Tifrany, op. cil. supra note 44 , at $2665, \S 646$.

133. See Morgan v. Smith, 70 N. Y. 537 (1877); (1933) 10 N. Y. U. L. Q. REv. 546. Williston writes: "On principle, it would seem that whenever two persons, or one person and the property of another, have come under an absolute liability without morc, there should be contribution regardless of the form of the undertaking, unless some contract between them or equitable considerations require a different result." WiLLISTON, op. cil. 
titled to contribution from his co-obligor for the latter's share of the debt. It is the writer's opinion that the owner last assuming should be placed by his assumption under a full primary liability regardless of whether his assumption was created by agreement with the mortgagor or the mortgagee. The credit on his purchase price of the amount of the mortgage, plus the benefits and strategic advantages of his fee ownership, are ample warrant for this, particularly after he has personally assumed the debt. A contrary rule exalts the technical concept of privity and leads to results which cannot be justified practically. Furthermore. if a grantee's assumption, by agreement with the mortgagor, is deemed to radiate enough beneficial intention toward the mortgagee to make the mortgagee a third-party beneficiary, ${ }^{13 !}$ a mortgagor may claim with equal cogency that he is a third-party beneficiary of an assumption made between the grantee and mortgagee.

\section{Mortgagor's Right of Exoneration; Mortg.igor's Right to Sue}

The mortgagor cannot require the mortgagee to foreclose on maturity. He may protect himself against enhancement of liability by paying the debt, taking an assignment of the bond and mortgage and proceeding against the land and an assuming grantee for indemnity. But even without payment of the debt the mortgagor may prevent an increase of liability. He may bring an action to compel an assuming grantee to discharge the mortgage or, in the alternative, have the premises sold for this purpose. This remedy of exoneration is well established. ${ }^{135}$ Its use is infrequent, however, probably because of mortgagors' inertia when the mortgage is adequately secured or reluctance to precipitate matters when the security is more dubious.

The mortgagor may also protect himself against increase of liability under the doctrine of Pain z'. Packard, ${ }^{130}$ a rule of suretyship law adopted in a minority of the states-in some, like New York, by the courts, and in others by statute. When the doctrine applies, the creditor's failure to enforce payment of the debt releases the surety to the extent of the loss thereafter sustained. The rule has been criticized, explained and qualified

supra note 14 , at $3647-18, \$ 1277 \mathrm{~A}$. Whenever several sureties are "equally bound" a right of contribution exists between them regardless of the chronological order in which the respective obligations were assumed. Newburger v. Lubell. 266 N. Y. 4, 193 N. E. 410 (1934) ; Yawger v. American Surety Co., 212 N. Y. 292, 106 N. E. 64 (1914).

134. See Friedman, supra note 5 , at 235-36.

135. See Marsh v. Pike, 10 Paige 595 (N. Y. Ch. 1844); Rubens v. Prindle, 44 Barb. Ch. 336 (N.Y. 1864) ; Marshall v. Davies, 7S N. Y. 414, 421 (1879); Glenn, Purcliasing Subject to Mortgage. First Phase: Mortgagor's Rights Against Grantee (1941) $27 \mathrm{VA}$. L. REv. 853, 868 ; but $c f$. Slauson v. Watkins, S6 N. Y. 597 (1S81) (action does not lie during pendency of foreclosure).

136. 13 Johns. 174 (N. Y. Sup. Ct. 1816). 
so extensively as to leave its precise limits in doubt. ${ }^{137}$ The chief objection to it is that it converts suretyship from an assurance of payment to a source of additional litigation. Under Pain $v$. Packard the surety's demand is ineffectual unless given after maturity ${ }^{138}$ and clearly demands the institution of an action against the principal. ${ }^{130}$ The rule was first applied to a situation where the principal-surety relationship existed at the inception of the obligation, and was justified on the basis of the presumed intention of the parties that payment be first sought from the principal debtor. It was then extended to situations where the principalsurety relationship was created between original clebtors by their clealings with each other, as in the case of a retiring partner. But it was not applied to collateral engagements made subsequent to the original obligattion upon independent consideration as, for example, an assignment of a mortgage with a guarantee of payment. ${ }^{140}$ Some recent cases, however, have applied the doctrine to a mortgagor who conveyed to a non-assuming grantee ${ }^{141}$ and have been criticized for their inconsistency with the established linitations. ${ }^{142}$ Further, they make a substantial inroad, without critical examination, upon the rule that the "primary liability" of the land has no application to the mortgagee. ${ }^{143}$

\section{Criticisim of SURetyship Rules}

Murray v. Marshall has been criticized on the ground that it imputes to the mortgagor, a primary obligor, the status of a surety when there is neither a "principal" debtor nor a request that the mortgagor become a surety. ${ }^{144}$ True, the conventional suretyship triangle is not present but similar logic might once have been urged against the creation of con-

137. For surveys of the rule of Pain w. Packard, see Comment (1928) 37 Yate L. J. 971 and L. R. A. 1918C 10. For qualifications of the rule, see More, Failure of Creditor to Sue Principal at Sitrety's Request (1929) 1 Rocky MT. L. Rev. 232.' See also STEARNS, op. cit. supra note $16, \S 16 ; 4$ WILIISTON, op. cit. supra note $14, \S 1236$.

138. The surety cannot require the creditor to accelerate the debt. Marks v. Follo, 177 Misc. 108, 29 N. Y. S. (2d) 1019 (Sup. Ct. 1941); Comment (1928) 37 Y ALE L. J. 971, 978.

139. For form of notice required, see Notes (1924) 30 A. L. R. 1285; (1911) 21 Ann. Cas. 1367; and authorities cited supra note 137.

140. See Newcomb v. Hale, 90 N. Y. 326 (1882).

141. See cases collected in Union Trust Co. v. Rogers, 261 App. Div. 882, 25 N. Y. S. (2d) 120 (4th Dep't 1941) ; Osborne v. Heyward, 40 App. Div. 78, 57 N. Y. Supp. 542 (2d Dep't 1899).

142. See (1935) 20 CoRN. L. Q. 249, criticising National Savings Bank v. Fermac, 241 App. Div. 204, 271 N. Y. Supp. 836 (3d Dep't 1934), aff'd, 266 N. Y. 443, 195 N. E. 145 (1934).

143. See Kmetz v. De Ronde, 231 N. Y. 641,132 N. E. 921 (1921); and compare note 11 stpra.

144. See Stevens, loc. cit. supra note 33. Professor Stevens' article advances other and more cogent criticism. 
structive and resulting trusts. There is no requirement that a surety be "requested" to act. ${ }^{145}$ Furthermore, the right of subrogation, and the penalty for its impairment, appears in situations other than that of conventional suretyship. Thus, if $A$ owns land affected by a judgment recovered against $B, A$ has a right that other lands of $B$ be sold first. $A$ also has a right, on payment of the judgment, to succeed to the rights of the judgment creditor by way of subrogation. But $A$ 's rights do not depend upon payment by him. If the judgment creditor releases a surety for the judgment without $A$ 's consent, equity will discharge the judgment lien from $A$ 's land. ${ }^{146}$

Calvo v. Davies and Murray $v$. Marshall can be justified only if a mortgagor who pays the debt finds that his remedy over against the land ur any person has been impaired by reason of an agreement made by the mortgagee and a subsequent owner. These casts presuppose that a mortgagor is bound by such agreement. ${ }^{147}$ A Pennsylvania case ruled directly to the contrary but a comment thereon states, that "this has never been adjudged." ${ }^{148}$ In a Connecticut case a mortgagor sold part of the mortgaged premises to an assuming grantee. The grantee extended the mortgage with the mortgagee. The mortgagor paid the mortgage, sued the grantee for reimbursement without awaiting expiration of the extension and recovered judgment. ${ }^{140}$ The court observed that continuous extensions would expose the mortgagor to risk of diminution of the value of the land sold and of his grantee's insolvency as well. It also observed that extensions would prevent a sale, mortgage or improvement of the mortgagor's remaining unsold land. Although not mentioned in the opinion, it would seem that the grantee alone lacked capacity to modify a mortgage on land only partly owned by him. In two New York cases it was held in effect that guarantors of mortgages were liable for interest at the original rate and not the increased rate effected by the extension agreements. ${ }^{150}$

It is not clear, therefore, how solid the logical foundation of the Cali'o and Murray cases is. But it is the merits of the rules which have been

145. See Miathews v. Aikin, 1 N. Y. 595 (1848).

146. See Barnes v. Mott, 64 N. Y. 397 (1876).

147. See Metzger v. Nova Realty Co., 214 N. Y. 26, 30, 107 N. E 1027, 1028 (1915); Brockton Savings Bank v. Shapiro, 311 Mass. 695, 42 N. E. (2d) $\$ 26$ (1942).

148. See Joyce v. Hawtof, 135 Pa. Super. 30, 4 A. (2d) 599 (1939), 5 U. or Pirr. L. REv. 286.

149. See Cacavalle v. Lombardi, 106 Conn. 339, 138 Atl 155 (1927).

150. See Excelsior Savings Bank v. Cohen, 176 App. Div. 740, 163 N. Y. Supp. 1017 (1st Dep't 1917), aff'd, $22 S$ N. Y. 570, 127 N. E. 912 (1920) ; Schwartz v. Smith, 143 App. Div. 297, 128 N. Y. Supp. 1 (1st Dep't 1911), aff'd, 207 N. Y. 714, 101 N. E. 1121 (1913). In both cases the guarantors' liability, for diffcrent reasons, survived the extension agreements. The decisions are questionable because, regardless of agreement, the creditor was entitled to the legal rate of interest after maturity. See test sispra at 781. 
subjected to modern attack. The criticism is obviously justified when a mortgagor is released by an extension made before or after maturity regardless of any effort on his part to invoke the remedies presumed to have been taken from him by the agreement. ${ }^{151}$ Cardozo has reduced to absurdity the "fictitious assumption that a surety, who has probably lain awake at night for fear that payment may some day be demanded, has in truth been smarting under the repressed desire to force an unwelcome payment on a reluctant or capricious creditor. The extended period has gone by; the surety has made no move, has not even troubled himself to inquire; yet he is held to be released on the theory that were it not for the extension, of which he knew nothing, and by which his conduct would not have been controlled, he would have come forward voluntarily with a tender of the debt." 152

Williston ${ }^{153}$ points out that ordinarily a creditor's delay is no defense to a surety ${ }^{154}$ and that a surety, with his equitable remedies to compel payment, ought not to expect any greater diligence of the creditor than he himself shows. All critics agree that if the surety has in fact been harmed, some relief should be given him, though there is no unanimity on the extent or means of achieving this result. If at the time of the extension the principal debtor is insolvent, any injury to the surety from the extension is illusory. But, as Durfee suggests, it is both inconvenient and unfair to make the surety prove the financial deterioration of the principal, though this is his duty under Pain v. Packard, or to make a release depend on the balance of injury and benefit of the extension agreement or the reasonableness or unreasonableness of the creditor's action. ${ }^{165}$ After a thoroughgoing investigation a New York law revisory commission recently recommended a statutory change whereby a surety would not be discharged by a change in the principal obligation except to the extent to which the surety is prejudiced thereby. ${ }^{150}$ This proposal was rejected, but it is difficult to disagree with its goal, based on Cardozo's suggestion, of "placing this branch of the law upon a basis more consistent with the realities of business experience and the moralities of life." ${ }^{157}$

151. See text supra at 780.

152. See Cardozo, op. cit. supra note 63, at 153-54. See also (1937) 4 U. of Cilr. I. Rev. 469, 472.

153. See Williston, op. cit. sitpra note $14, \S 1225$.

154. See Glacius v. Fogel, 88 N. Y. 434 (1882) ; Newcomb v. Hale, 90 N. Y. 326 (1882) ; Kings County Trust Co. v. Derx, 237 App. Div. 548, 261 N. Y. Supp، 909 (2d Dep't 1933). See also text supra at 786.

155. Durfee, Book Review (1932) 17 Cons. L. Q. 707.

156. Report of N. Y. LAw Revis. Coarm. (1937) 875 at seq. The propased statute was expressly inapplicable to retired partners and parties secondarily liable on negotiablo instruments.

157. CAmbozo, op. cit. supra note 63 , at 155. 